\title{
Teaching Undergraduate Social Statistics Online: A Classroom Assessment of Instructional Interventions to Reduce Statistics Anxiety and Facilitate Student Success
}

\author{
Allison R. Reagan \\ Texas Woman's University \\ Department of Sociology and Social Work \\ Post Office Box 425887, Denton, Texas 76204-5887 \\ USA
}

\begin{abstract}
Instructional interventions for teaching introductory social statistics courses online differ from those used when teaching in traditional on-campus courses. Despite the expansion in online course offerings to accommodate the high rate of university sociology programs which require social statistics to graduate, a gap exists in scholarship regarding empirically-based recommendations for effective pedagogical online course design and implementation strategies. In this manuscript, I describe my experiences teaching and creating undergraduate social statistics courses designed to minimize student challenges for learning statistics online by incorporating innovative pedagogical strategies and interventions. Additionally, I report students' perceptions of the usefulness of the pedagogical course design strategies and instructional interventions in reducing their statistics anxiety and success in learning course material. The data for this qualitative classroom assessment was collected from six sections of online undergraduate introductory-level social statistics courses. The results can guide online instructors, researchers, and course designers.
\end{abstract}

Keywords: Academic Self-Efficacy, Distance Statistical Education Pedagogy, Higher Education Research, Instructional Interventions, Online Course Design, Teaching Undergraduate Statistics

\section{Introduction}

Over $75 \%$ of national universities require undergraduate sociology majors to successfully complete at least one statistics course (Delia Deckard, 2017). In an effort to facilitate student access to courses that are required for graduation, the trend among universities is to widen access beyond the traditional on-campus model of delivery by utilizing technology to offer courses that are delivered online (Kinghorn, 2014). Allen and Seaman (2010) reported an increased demand for online degree courses. In light of this trend, instructors are tasked with redesigning their traditional on-campus courses into courses that can be delivered online. For undergraduate online social statistics course instructors, this task can be particularly difficult due to the significant challenges related to teaching and learning statistics. The increase in online statistical education has led to a heightened interest in the best practices for teaching and designing online courses by statistical education researchers and instructors. Over the past decade, academics and researchers have produced an extensive body of scholarship of teaching and learning (SoTL) research regarding curricular content and the Guidelines for Assessment and Introduction in Statistics Education (Franklin \& Garfield, 2006). However, minimal current scholarship exists within the discipline of sociology regarding instructional interventions to minimize anxiety and facilitate student success in online social statistics courses.

This article bridges the gap in knowledge by reporting research with undergraduate social science students who completed their social statistics requirement in one of the online social statistics courses in which I teach. Specifically, the objective of this paper was to describe the pedagogical practices and instructional interventions used by one sociological educator to design and deliver introductory-level, undergraduate social statistics courses online and the reactions of her students to these interventions. 


\subsection{Background: Classroom Observations and SoTL Pedagogical Responses}

I was extremely excited to have the opportunity to teach the social statistics course. When I told a colleague that I was assigned the course, she gave me her condolences. I was puzzled as to why she responded in this manner until she shared with me that the consensus among our graduate teaching assistant (GTA) colleagues was that this was the most difficult undergraduate course within our department to teach. Unsurprisingly, the challenges experienced by the GTAs within our department were not isolated incidences. There are many challenges to teaching statistics, including the following barriers: high levels of student statistics anxiety (Onwuegbuzie, 2004; Pan \& Tang, 2005), which is defined as, "anxiety that occurs as a result of encountering statistics in any form and at any time" (Onwuegbuzie, DaRos, \& Ryan, 1997, p. 28); fear of failing the course and delayed graduation (Onwuegbuzie, 1997); and lack of academic self-efficacy (Schacht \& Stewart, 1990) are extensively studied within the scholarship of teaching and learning (SoTL) and statistics education literature. Further, Dykeman (2011) found that when compared with students enrolled in general education courses, students in statistics courses had higher levels of anxiety and lower levels of self-efficacy. Unfortunately, statistics anxiety (Onwuegbuzie \&Seaman, 1995) and low self-efficacy negatively affect learning, course performance, and engagement in research (Schacht \& Stewart, 1990).

I have kept a teaching journal since the first day of the very first class that I taught. Upon reflection of student course introductions, while teaching my second section of social statistics, I noticed a pattern among student introductions that were similar to the first section that I taught. This was concerning because the nature of the student's discontent/fear could potentially impact their success in the course. The pattern of comments emerged into the following main themes: (a) high levels of statistics anxiety (specifically lack of perceived skills in math, test taking anxiety/failure and not graduating, the way in which their learning style might hinder them in learning a difficult subject online, and communicating with a statistics instructor) and (b) frustration for being required to enroll in and successfully complete the social statistics course as part of the degree plan due to lack of perception of perceived value in the real world. There appeared to be a variability or, in other words, a disconnect between instructors' perceived student resource need, which informs their pedagogical strategies and instructional interventions used to teach the course with students attitudes towards their actual academic needs, andwhat are useful resources for them in successful completing social statistics.

\section{Classroom Assessment Methodology}

\subsection{Objectives}

My objective was to design a research-based pedagogical strategy for facilitating student access to statistical knowledge and self-efficacy resources while minimizing statistics anxiety in the online undergraduate-level social statistics courses in which I teach (Dykeman, 2011). The first stage involved merging my teaching philosophy and best practices for teaching and learning online to formalize course policies which would serve as the foundation for the online learning environment architecture. The second stage included the creation of the online learning environment (i.e., course shell) which included the instructional interventions. This was a challenge, as it needed to be flexible to accommodate the diverse student learning styles while also maintain a rigidly-standardized architecture so students could rely on accessing consistently formatted course content, assignments, assessments, and student support resources within each course module. The last stage in the design process was to build a classroom assessment infrastructure that would not add to the already high levels of statistics anxiety but would allow for the systematic collection of data to evaluate students' perceived value of the instructional interventions in reducing their statistics anxiety and in helping them learn course content.

\subsection{Field Site, and Sample Population}

The field site for this action-based-classroom-assessment research was conducted virtually within the online learning environments of six sections of social statistics courses that I taught in 2017 and 2018 for the department of sociology and social work at Texas Woman's University. The Department of sociology and social work requires successful completion of this course for criminal justice and sociology majors. In other words, undergraduate criminal justice students must earn a minimum grade of a C (Texas Woman's University, 2018). Even though I teach social statistics on campus and online, the population for this research consisted of the following groups of undergraduate students who elected to enroll in SOCI 3163 Social Statistics online: FA/17 two online sections, SP/18 one online section, SU/18 one online section, and FA/18 two online sections. 


\subsection{Data Collection and Analysis}

This classroom assessment was designed to include data that was related to normal educational practices within the online learning environment. This data collection method follows the new online course design framework that I propose within my dissertation. In other words, I intentionally did not conduct any formal student interviews for two reasons. First, I did not want to further exacerbate students' statistics anxiety by adding an additional task to their already packed schedules. Second, most importantly, I did not want to potentially capitalize on students fear of course failure, and/or fear of statistics instructors by potentially feeling coerced to participate in a formal interview that they do not want to because they are afraid that non-interview-participation would impact their course grade (Miser 2005). Classroom assessment data includes instructor observations and qualitative student feedback. The instructor observational data was collected from my teaching journals, discussion board posts, as well as instructor-student interactions. The student data includes student responses made in the completion of homework 3, homework 6, and final essays (Miser, 2005; University of Nebraska-Lincoln, 2017). These data were collected with the course learning systems (i.e., Blackboard or Canvas) that were used to deliver each section of the online course. This de-identified data was aggregated by semester/section to evaluate students' perceived value of the instructional intervention's usefulness in reducing statistics anxiety and to identify which instructional interventions (i.e., methods) enhanced their ability to learn statistics (Pan \& Tang, 2005).

\section{Designing an Online Introductory Social Statistics Course}

\subsection{Curricular Design}

The following is the course description printed in the university catalog: "SOCI 3163.Social Statistics. Introduction to basic statistical techniques in the social and behavioral sciences and data analysis using computers. Basic descriptive statistics, measures of central tendency and variation, normal curve, hypothesis testing, $\mathrm{t}$ tests, ANOVA, chi square test, measures of association, regression and correlation. Three lecture hours a week. Credit: Three hours" (Texas Woman's University, 2018). This course has five student learning outcomes. Upon successful completion of this course, students will be able to: (1) Explain basic concepts in social statistics. (2) Choose appropriate statistical techniques based on research questions and data. (3) Interpret statistical data. (4) Apply statistical techniques to answering research questions. (5) Perform social data management and analysis using SPSS for Windows.There were two required textbooks for the course, Frankfort-Nachmias and LeonGuerrero2018 Social Statistics for a Diverse Society, $8^{\text {th }}$ ed. and Babbie, Wagner, and Zaino 2018 Adventures in Social Research: Data Analysis Using IBM® SPSS® Statistics, $10^{\text {th }}$ ed.

\subsection{Syllabus}

The syllabus was a carefully crafted pedagogical tool that is one of the major components in creating an effective learning environment (Addison, Stowell, \& Reab, 2015). As such, it was designed to not only be a comprehensive resource for students (i.e., listing policies, assignments, and grading), but also as an instructional intervention for building emotional rapport with students (i.e., teaching philosophy, student support, and student academic resources) (Addison, Stowell, \& Reab, 2015; Waples, 2016).

\subsection{Instructional Intervention: Course Communication Architecture A Student-Instructor Relationship Management Framework}

In addition to promptly responding to communications initiated by students, each semester I implement an instructor-student communication strategy (see Table 1) for ways in which I initiated contact with students. The communication framework is composed of two main elements: pre-scheduled private communications and prescheduled pre-programed group announcements. This framework is easy to apply semester-after-semester by simply changing the instructor calendar reminder dates and announcement release dates. 
Table 1. Calendar of Communication, fall 2018

\begin{tabular}{|c|c|c|c|c|}
\hline $\begin{array}{l}\text { Week\& } \\
\text { Module }\end{array}$ & & Course Topic & $\begin{array}{l}\text { Date } \quad \& \quad \text { Type } \\
\text { Communication }\end{array}$ & Nature of Communication \\
\hline \multirow{2}{*}{\multicolumn{2}{|c|}{$\begin{array}{l}\text { Pre-Course } \\
0\end{array}$}} & \multirow[t]{2}{*}{$\mathrm{n} / \mathrm{a}$} & $8 / 19 / 18, \mathrm{GA}$ & Welcome to class with list of course texts and supplies \\
\hline & & & $8 / 26 / 18, \mathrm{GA}$ & $\begin{array}{l}\text { Welcome to class: acknowledges statistics anxiety, lays ground work for value of } \\
\text { statistics (Onwuegbuzie et al. 2010), and provides an overview of navigating } \\
\text { Blackboard/Canvas. }\end{array}$ \\
\hline \multirow{2}{*}{\multicolumn{2}{|c|}{$\begin{array}{l}\text { Week } 1 \\
\text { Module } 1\end{array}$}} & \multirow{2}{*}{$\begin{array}{l}\text { What \& Why of } \\
\text { Statistics }\end{array}$} & $8 / 27 / 18, \mathrm{GA}$ & Preparing for module 1 \\
\hline & & & $\begin{array}{l}\text { Mon-Sun, } \\
\text { Feedback }\end{array}$ & $\begin{array}{l}\text { Post my introduction DB. } \\
\text { Respond to all introduction discussion posts. }\end{array}$ \\
\hline \multirow{2}{*}{\multicolumn{2}{|c|}{$\begin{array}{l}\text { Week } 2 \\
\text { Module } 1 \\
\text { *Labor } \quad \text { Day } \\
\text { Holiday }\end{array}$}} & \multirow[t]{2}{*}{$\begin{array}{l}\text { What \& Why of } \\
\text { Statistics }\end{array}$} & $9 / 3 / 18, \mathrm{SPC}$ & $\begin{array}{l}\text { Sent to all students who missed an assignment in module } 1 \\
\text { "I noticed that you missed X assignment(s) in module } 1 \text { is there anything that I can do to } \\
\text { help you be successful in this class? Please let me know, I am here to help." }\end{array}$ \\
\hline & & & 9/09/18, GA & Preparing for module 2 \\
\hline \multirow{2}{*}{\multicolumn{2}{|c|}{$\begin{array}{l}\text { Week } 3 \\
\text { Module2 }\end{array}$}} & \multirow{2}{*}{$\begin{array}{l}\text { Organization \& } \\
\text { Graphic } \\
\text { Representation of } \\
\text { Data }\end{array}$} & 09/10/18, Feedback & Discussion board \\
\hline & & & $09 / 16 / 18, \mathrm{GA}$ & Preparing for module 3 \\
\hline \multirow{2}{*}{\multicolumn{2}{|c|}{$\begin{array}{l}\text { Week } 4 \\
\text { Module3 }\end{array}$}} & \multirow[t]{2}{*}{$\begin{array}{l}\text { Measures of Central } \\
\text { Tendency }\end{array}$} & $\begin{array}{l}\text { 09/17/18, } \\
\text { Feedback }\end{array}$ & Discussion board \\
\hline & & & $09 / 23 / 18, \mathrm{GA}$ & Preparing for module 4 \\
\hline $\begin{array}{l}\text { Week } 5 \\
\text { Module4 }\end{array}$ & & $\begin{array}{l}\text { Measures of } \\
\text { Variability }\end{array}$ & $\begin{array}{l}09 / 24 / 18 \\
\text { Feedback }\end{array}$ & Discussion board \\
\hline \multirow{2}{*}{\multicolumn{2}{|c|}{$\begin{array}{l}\text { Week } 6 \\
\text { Module4 }\end{array}$}} & \multirow[t]{2}{*}{$\begin{array}{l}\text { Exam } 1 \text { Review } \\
\text { Exam } 1\end{array}$} & $\begin{array}{l}\text { 10/01/18, GA \& } \\
\text { Feedback }\end{array}$ & $\begin{array}{l}\text { Discussion board } \\
\text { Exam } 1 \text { information and review }\end{array}$ \\
\hline & & & 10/07/18, GA & Preparing for module 5 \\
\hline \multirow{2}{*}{\multicolumn{2}{|c|}{$\begin{array}{l}\text { Week } 7 \\
\text { Module5 }\end{array}$}} & \multirow[t]{2}{*}{$\begin{array}{l}\text { Normal Distribution } \\
\text { Sampling } \\
\text { Distribution }\end{array}$} & 10/08/18, SPC & $\begin{array}{l}\text { Send to all students with a total score below the median and/or } 3 \text { or more missing } \\
\text { assignments. "I wanted to check in with you since we are approximately half way } \\
\text { through the semester so see how you are doing and ask if there any resources that might } \\
\text { help you be successful in our class?" }\end{array}$ \\
\hline & & & $\begin{array}{l}10 / 08 / 18 \\
\text { Feedback }\end{array}$ & Exam 1 \\
\hline \multirow{2}{*}{\multicolumn{2}{|c|}{$\begin{array}{l}\text { Week } 8 \\
\text { Module } 5\end{array}$}} & \multirow{2}{*}{$\begin{array}{l}\text { Normal Distribution } \\
\text { Sampling } \\
\text { Distribution }\end{array}$} & $\begin{array}{l}10 / 15 / 18 \\
\text { Feedback }\end{array}$ & Discussion board \\
\hline & & & 10/21/18, GA & Preparing for module 6 \\
\hline $\begin{array}{l}\text { Week } 9 \\
\text { Module6 }\end{array}$ & & Testing Hypotheses & $\begin{array}{l}10 / 22 / 18 \\
\text { Feedback } \\
\end{array}$ & Discussion board \\
\hline \multirow{2}{*}{\multicolumn{2}{|c|}{$\begin{array}{l}\text { Week } 10 \\
\text { Module } 6\end{array}$}} & \multirow[t]{2}{*}{$\begin{array}{l}\text { Exam } 2 \text { Review } \\
\text { Exam } 2\end{array}$} & $\begin{array}{l}\text { 10/29/18, } \\
\text { GA \&Feedback }\end{array}$ & $\begin{array}{l}\text { Discussion board } \\
\text { Exam } 2 \text { information and review }\end{array}$ \\
\hline & & & $11 / 04 / 18, \mathrm{GA}$ & Preparing for module 7 \\
\hline $\begin{array}{l}\text { Week } 11 \\
\text { Module7 }\end{array}$ & & $\begin{array}{l}\text { Bivariate Tables, } \\
\text { Chi-Square, and } \\
\text { Measures of } \\
\text { Association }\end{array}$ & $\begin{array}{l}11 / 05 / 18 \\
\text { Feedback }\end{array}$ & $\begin{array}{l}\text { Discussion board } \\
\text { and exam } 2\end{array}$ \\
\hline $\begin{array}{l}\text { Week } 12 \\
\text { Module7 }\end{array}$ & & $\begin{array}{l}\text { Bivariate Tables, } \\
\text { Chi-Square, and } \\
\text { Measures of } \\
\text { Association }\end{array}$ & $\begin{array}{l}\text { 11/18/18, } \\
\text { GA\&SPC }\end{array}$ & $\begin{array}{l}\text { Preparing for module } 8 \\
\text { Send to all students with a total score below the median and/or } 3 \text { or more missing } \\
\text { assignments. "I wanted to check in with you now that you have completed two exams to } \\
\text { see if there are any resources that would be helpful for you to study for the final } \\
\text { examination? }\end{array}$ \\
\hline $\begin{array}{l}\text { Week } 13 \\
\text { Module8 } \\
\end{array}$ & & ANOVA & & *holiday week \\
\hline \multirow{2}{*}{\multicolumn{2}{|c|}{$\begin{array}{l}\text { Week } 14 \\
\text { Module8 }\end{array}$}} & \multirow[t]{2}{*}{ ANOVA } & $\begin{array}{l}11 / 26 / 18 \\
\text { Feedback }\end{array}$ & Discussion board \\
\hline & & & $12 / 02 / 18, \mathrm{GA}$ & Preparing for module 9 \\
\hline $\begin{array}{l}\text { Week } 15 \\
\text { Module } 9\end{array}$ & & $\begin{array}{l}\text { Regression and } \\
\text { Correlation }\end{array}$ & $\begin{array}{l}\text { 12/03/18 } \\
\text { Feedback }\end{array}$ & Discussion board \\
\hline $\begin{array}{l}\text { Week } 16 \\
\text { Module9 }\end{array}$ & & Exam 3 & 12/10/18, GA & Exam 3 information and review \\
\hline
\end{tabular}




\subsubsection{Pre-Scheduled Private Communications}

These are scheduled private instructor-student email communications (SPC) to discuss course performance issues with low-achieving students (Connors, Mccown, \& Roskos-Ewoldsen, 1998). These students are identified by their total numerical grade that is below median and/or missing 3 or more assignments during a designated point of time. Typically, I use a personalized 'form-letter' email to initiate and open a dialogue about a particular issue. These emails are not sent to all students, rather only to students who fall within the guidelines for that communication (i.e., missing assignment, mention struggling with topic on discussion board, low grade on a quiz and did not take the opportunity for multiple attempts). These are classified as SPC in Table 1.I have never received a negative response to these emails. Following are just a few of the response comments:

"Thank you so much for reaching out to me...You have no idea how much this means!"

"Professor Reagan! Thank you so much for reaching out! That is really awesome, I have never really had a teacher do that before."

"Oh my goodness thanks for messaging me!"

\subsubsection{Pre-Scheduled, Pre-Programmed Group Communications}

This type of communication includes scheduled group announcements (Depicted in Table 1 as GA) that I manually input into the course delivery management system prior to the course opening for students each semester. I created each group announcement as an individual post by copying and pasting the content of the announcement from a word file and then selecting the announcement release date. Announcements are the released by Blackboard/Canvas on the release date to each student enrolled within a particular semester and course section. Students most often mentioned the orientation/welcome announcement and the new module announcements are useful for helping them learn course material. I send an orientation/welcome through Blackboard/Canvas to all enrolled students approximately one week before the online course shell opens. This announcement looks like a personalized email and includes the required textbooks, where and how to access a free copy of SPSS, and student support resources (Pan \& Tang, 2005).

\subsection{Designing the Learning Activities Structure \& Assessments}

Course design and delivery contribute to successful online learning (Stone \& Perumean-Chaney, 2011). The following section of this paper details the design and implementation of the learning activities assigned within the undergraduate online social statistics course.

\subsubsection{Discussion Board}

This active-learning pedagogical strategy is included as part of the course architecture to facilitate a communitycentered online learning environment that values learning from one another (Bransford, et al., 2005) with application-oriented learning experiences (Pan \& Tang, 2004) where students can also practice using statistical language (Forte, 1995). Each module has a major and minor discussion board. The major post (valued at 15 points) prompts are tailored each semester based on student responses regarding their personal and future professional interests in the introduction discussion board to facilitate active application of SPSS and deep learning. The minor posts (valued at 5 points each) requires a response to a classmate's major post. Typically, one of the most active discussion board (DB) discussions is the 'Getting Started: Introductions' board. On this DB, students respond to the following prompt, "Please take a few minutes to write a narrative introduction about yourself. A narrative is essentially a story about you- feel free to be as creative as you would like and to tell us as much or as little as you are comfortable with. You are welcome to add photos, videos, or other media to enhance the written narrative. If you are not sure where to begin your story or what to include, I have listed questions below.

I have also posted my narrative on the discussion board so you can get to know me better. What is your academic classification? What is your major? What do you want to do for a career when you graduate? What do you like to do in your free time? What do you feel is your greatest talent? Have you taken an online class before? What do you need from me more than anything else? Describe your favorite online instructor, what types of things did they do in their class that you liked? Describe your least favorite online instructor/course (no names please). If you were the teacher, what would you have done differently? What resources do you feel you need to be successful in this class? How do you think statistics might help you advance professionally?'This assignment serves multiple purposes. First, it allows students to familiarize themselves with completing a DB on Blackboard/Canvas. Second, the discussions help to build an online learning community. 
Lastly, I can use the information that they share to shape the types of student resources provided, course design, and content of future assignments based on the learning styles and content interests of each section of the course.

\subsubsection{Homework and Quizzes: Instructional Intervention Multiple Attempts and Grading}

Chew and Dillion (2012) studied academic procrastination and statistics anxiety and reported that weekly assignment such as quizzes are effective pedagogical interventions to help students minimize procrastination of required readings. Each learning module includes a quiz and a homework assignment. The quizzes are composed of a maximum of 15 multiple choice test bank questions that were chosen to reinforce concepts within that modules required readings (Pan \& Tang, 2005). Homework assignments include approximately 10 applicationbased questions offered in a randomized order, one question at a time, with backtracking prohibited. Students have 3 opportunities to complete each module homework and quiz and earn the score of their highest attempt prior to the due dates listed in the course calendar. This strategy was designed to minimize test taking anxiety by providing multiple opportunities to fail and relearn course content without impacting their grade which is supported by Ferrandino (2016) and Kapur's (2015) research. The productive failure strategy (Kapur,2015) not only minimizes test taking anxiety by deemphasizing fear of failure but also turns the once intimidating assessment into a learning tool (Ferrandino, 2016).

\subsubsection{Instructional Intervention: Homework and Quiz Feedback Strategy}

Finney and Schraw (2003) studied the relationship between students' self-efficacy and learning statistics. The authors suggested that providing encouragement and course performance feedback impacts students' self-efficacy (Finney \& Schraw, 2003). To improve on Ferrandino's (2016) study which also provided students with multiple opportunities to complete assignments but delivered feedback only after the time to complete the assignments had passed. I programmed each homework assignment and quiz into Blackboard/Canvas to automatically grade and provide feedback upon submission. When student's correctly answering a question, they receive feedback note such as, "Correct answer-Good Job." When a student incorrectly answers a question, they receive a feedback note such as, "Incorrect response" with detailed resources to clarify the content of the question. The feedback is formulated as a mini-lesson containing the following: reference to course text bookswith the corresponding page numbers where the content in question is presented, step-by-step instructions for answering the question (when applicable), and/or additional similar example. Higher test and quiz scores on average, were reported for students who received immediate feedback (Butler, Pyzdrowski, Goodykoontz \& Walker, 2008). Butler, Pyzdrowski, Goodykoontz and Walker's (2008) research support the value of providing immediate feedback. I coded this feedback for a few reasons. First, a large number of students shared in their course introductions that it was extremely frustrating to wait for instructors to grade assignments and deliver feedback because this delay impacted their ability to learn the material and successfully complete other assignments. Second, when I first started teaching social statistics I spent over 10 hours (per module, per section of each course) grading and emailing feedback to individual students. While I value the feedback process, this process was slow and wasted valuable teaching time.

\subsubsection{Instructional Intervention: Use of Humor in Homework and Quiz Assignments}

The syllabus quiz is an ideal example to illustrate a pedagogical approach for instructors can use an assessment as a learning tool to build student self-efficacy (for successful course completion) and rapport. This quiz is the first assignment that students complete in the course. It is a short quiz that features easy to answer multiple choice questions which focus on information contained within the course syllabus. I always incorporate at least one humorous question to help students remember course objectives and to humanize myself as the instructor (Onwuegbuzie et al., 2010; Zimmerman \& Johnson, 2017).

One student commented, "I just wanted to thank you for the humor in the quiz. I appreciated the last question. I honestly laughed out loud...I laughed and felt the need to let you know that it was appreciated. I am looking forward for this class."

I have found that the syllabus quiz serves to fulfill many functions such as: (a) a low-stakes assignment to familiarize themselves with completing a quiz on Blackboard/Canvas, (b) minimizer of unnecessary student emails regarding information contained in the syllabus, and (c) unrelatable-statistics-instructor myth buster by dispelling commonly held preconceived notions that statistics instructors are difficult to communicate with. Additionally, even though I did not measure course completion rates in this study, Zimmerman and Johnson (2017) studied the relationship between course completions and first quiz score. The authors reported that a 
student's score on the first quiz in a course is a valid predictor of successful course completion and suggest that it can be used to identify at-risk students for targeted instructional interventions (Zimmerman \& Johnson, 2017).

\subsubsection{Homework as Feedback Survey}

The third and sixth homework assignments include course survey questions which give the students the opportunity to provide feedback on course structure, assignments, and instructor factors. Each student could anonymously respond to questions with their opinions or select the "I do not want to respond" answer to each question. The feedback surveys were anonymous (the online grade book indicated completion with a checkmark next to students name) and received automatic full points upon submission. Multiple researchers report that this type of instructional intervention (i.e., informal class feedback surveys) which empower students with the opportunity to share their opinions to influence the direction of the course, reduced statistics anxiety (Pan \& Tang, 2005; Everson \& Garfield, 2008).

\subsubsection{Examinations}

The course includes three examinations which are valued at 100 points each. To minimize test taking anxiety the multiple choice and essay examinations are structured as follows. Each exam allows only one attempt, however that one attempt is available for three days. Once opened, the exam shows randomized questions, one at a time, and prohibits back tracking. The exam can be opened and saved until the due date at which time the exam closes and is no longer available.

\section{Online Learning Environment Structure}

\subsection{Course Shell Content Presentation}

The online learning environment (i.e., course shell) follows the same nine module format as the course syllabus. This practice of routinization is supported by Macheski, Lowney, Buhrmann, and Bush (2008) who found that creating common formats for assignments and course patterns reduces student anxiety because they know what to expect. I consistently presented of all course assignments and materials using the same format within each module. For example, each module begins with an overview containing the reading assignments and objectives. This is followed by an assignments folder with contains a quiz, discussion board, and homework assignment. The last folder within each module is titled 'resources' and contains PowerPoints ${ }^{\circledR}$, mini-lessons, videos, web resources, and SPSS quick guide.

\subsection{Instructor Information Course Shell Page}

Following Zimmerman and Johnson's (2017) suggestions to humanize statistics instructors, I designed an 'Instructor Contact Information' page with personal images and a jargon-free narrative introduction. Within the page, I acknowledge the different forms of statistics anxiety, and discussed my excitement about teaching statistics. This page also includes links to subpages that share information about the following topics: (a) list of menu items with descriptions for each section of the course, (b) typical structure of each learning module, (c) list of technology requirements, (d) information about accommodations and contact information for TWU's disabilities support services.

\subsection{Student Resources Course Shell Pages}

In an effort to facilitate student self-efficacy and learning, each module within the course has student resources available to provide additional avenues for learning the course material. Since not all students learn in the same way, the resources are presented in multiple formats which may include: mini-lessons, videos, case studies, supplementary PowerPoints ${ }^{\circledR}$, links to university resources (i.e., the Mathematics and Technology Success Center, Smart thinking), online applets or games, clickable module checklist, and grade calculation worksheet.

\subsubsection{Mini-Lesson Course Shell Pages}

Each module includes a mini-lesson or re-teaching documents for download based on the questions from oneminute-papers in my on campus classes, emailed questions about commonly misunderstood content from previous classes, and step-by-step SPSS examples.

\subsubsection{Power Points and Videos}

Each module contains PowerPoints for each book chapter; I add funny examples and cartoons to add humor (Schacht \& Stewart, 1990). I also provide direct links to TED Talk and YouTube videos.

\subsection{Learning Assessment Grade Calculation Sheet}


This self-efficacy tool helps students keep track of exactly where they are in the course grade wise while also selfassessing their future learning strategies. The worksheet is set up in table format. The first column lists the module number and the maximum possible cumulative points (MCP). For example, in module one, the maximum possible cumulative points column shows the following formula: $\mathrm{MCP}=(20+25+15+5+25+25)=115$. The second column displays the learning assignments for that module while the fourth column displays the associated maximum point values. The fifth column is left blank for the student to enter their earned points for each assignment and the sixth column is titled "future learning strategies to consider". This is where students can make note of either why they were successful on this assignment so they can model the behavior for future assignments or note other learning strategies to try on future assignments if they were less than successful.

\section{Findings and Discussion}

In the redesigned undergraduate-level social statistics course, students were expected to successfully learn basic statistical techniques and data analysis using computers (Texas Woman's University, 2018). The statistics course had five learning objectives; the students' competencies were measured throughout the semester. Each student's learning mastery was assessed directly with quizzes, homework assignments, examinations, and discussion board posts (Lo, 2010). This study also used indirect measures (Lo, 2010) which consisted of student's opinion about the helpfulness of instructional interventions; results are presented in Table 2 below.

Table 2. Student Perceptions of Instructional Interventions

\begin{tabular}{|l|l|}
\hline Instructional Intervention & $\begin{array}{l}\text { Responded 'yes' } \\
(\mathrm{n}=96)\end{array}$ \\
\hline Homework helpful as learning tool & $88.5 \%$ \\
\hline PowerPoints® helpful as learning tool & $81.2 \%$ \\
\hline Assignments due throughout the week & $62.5 \%$ \\
\hline PowerPoints® (would be more useful with voice over?) & $44.8 \%$ \\
\hline Videos helpful as learning tool & $46.1 \%$ \\
\hline
\end{tabular}

The following comments were made by students in response to the question, "Do you feel that receiving automatic feedback from the homework questions that you answered incorrectly is better than waiting for a professor to grade homework and then provide feedback?

Yes, I find it very helpful. I have always disliked when in my previous courses I simply received a grade and no correct answer or feedback. I feel that it leads me to go uncertain the entire course. Yes, it allows me to review right away without any interruptions since I always do my homework after I have put my kids to bed. The feedback received immediately is helpful because the information is fresh in my brain. Professors are not always able to email back immediately. Yes, I like to complete the work and see what I missed. This lets me know my weaknesses and what I need to focus on more. There have been times I have had to skip a question because I wasn't sure how to answer, but I knew I could get feedback, revisit the material and try to get a better understanding, go back and do the homework again and improve my grade. Reading, writing out or reworking homework (more than once) is like anything else, more practice, which helps ensure a better understanding of the material.

The following comments were made by students in response to four survey questions asking if the multiple opportunities to complete quizzes and homework helps them learn course material and if these pedagogical tool helps to reduce statistics anxiety.

Yes, this course is required for my degree so I have to have a $C$ or better and I feel like I am not adequate naturally in statistics. Juggling as much as I have going on in life, this makes it possible for me to succeed in this course.Yes, it allows me to see what I did wrong and correct it. It truly defines what "learning" should be. If I were to only be given one chance I would probably look at my grade and move on, not even try to see what I did wrong or try to master it. Also, taking the stress factor out of only having one chance to know the information does help. Yes, having three opportunities to take a quiz has greatly reduced my stress level with this course because, as with the homework, knowing I have more than once chance to test my knowledge and being able to go back and study the material again, really helps me not to stress too much over a quiz. This is good for someone like me who has always had test anxiety, whether I know the information or not, I always get nervous and tend to 
over- think tests and quizzes. Knowing I have more than one shot at the quiz completely takes the anxiety out of it, for me.

When asked, "So far this semester, what has been the best aspect of this course?" more than half of the students commented about the multiple opportunities to learn the material on quizzes and homework assignments, the modular resources, and the course structure.

The chance to take the quizzes and homework over without feeling unsuccessful. The ability to retake quizzes and homework assignments. It allows the opportunity to rework mathematical problems, or re-read text to find the correct answer and validate that I've corrected my understanding. The resource materials I have found that the professor has provided is the best aspect of this course to me thus far.The PowerPoint ${ }^{\circledR}$ always helps clarify what I read in a concise way.I like that there are so many activities and that they are so spaced out so I have a better chance of completing tasks on time. I really appreciate this because I have another online class that does not do this and I have forgotten assignments. The course is well organized and I feel confident working with materials because I am given multiple resources to help me.

A pattern emerged among the remaining $40 \%$ of student feedback comments. Typically, the comments regarding what was valuable for increasing their success in the course could be classified into one of the following themes: communications/announcements; a 'safe' online course environment; instructor empathy, flexibility, and humor; and discussion board interactions.

I am extremely pleased with the amount of effort given from the instructor to promote success in this class. I like the course announcements each week. The vocabulary and summaries for each module are very helpful for me going into each week because they give me very clear expectations. The feedback/reviews of the homework assignments also let me specifically note what I will need to spend more time on before I move forward.My favorite part so far was the introduction quiz and post. I loved the humor you had and getting to my classmates. Honestly, your humor and attempts to put us at ease in a class that maybe seems a little scary at first and then is made scarier because it's a graduation requirement for Sociology majors. I also very much appreciate your prompt grading and comments on assignments.

\section{Recommendations and Conclusion}

Numerous scholars who research how to effectively design and teach online introductory statistics courses have noted the challenges for teaching and learning statistics (Addison, Stowell, \& Reab, 2015; Dykeman, 2011; Everson \& Garfield, 2008; Kapur, 2015; Pan \& Tang, 2004; Waples, 2016). Designing and implementing an online statistics course with empirically-based instructional interventions can minimize those challenges. First and foremost, I would recommend that instructors incorporate anxiety reducing pedagogical strategies. Out of all six sections that I taught, only 6 of the 96 students who responded to the survey reported not feeling stressed or having statistics anxiety on the first day of class. Second, while I made every effort to incorporate as many of the student feedback suggestions as possible, there were a few excellent suggestions that I was not able to accommodate due to time and technological constraints. As such, I would suggest that future researchers and instructors consider incorporating and assessing the following student requested resources:(a) SPSS activities with corresponding instructor videos, (b) auditory components such as video and/or audio instructor lectures, (c) videos with step by step instructions, and (d) voiceover PowerPoints®.With regards to future research, this research could be enhanced by including and exploring the following: (a) student course completion rate to measure student retention (i.e., drop-outrate) and (b) student success rate to measure the rate of successful course completion (i.e., the rate of students who successfully complete the course with a minimum grade of c).

In conclusion, this classroom assessment explored student perceptions of instructional interventions designed to increase learning and minimize statistics anxiety. The findings contribute to teaching and learning scholarship in two distinct ways. First, as a resource for statistics educators and researchers, by adding new practical empirically-based insights regarding innovative teaching interventions (i.e., multiple attempts, automatic feedback, extended exam time, consistent structure, communications strategy) which contribute to the literature on teaching and learning statistics in higher education. Second, the description of the ways in which to construct an effective online statistics course shell with student support and academic resources that minimizes statistics anxiety while facilitating learning is helpful to statistics educators and course builders. 


\section{References}

Addison, W.W., Stowell, J.R., \& Reab, M.D. (2015). Attributes of introductory psychology and statistics teachers: Findings from comments on RateMyProfessor.com. Scholarship of Teaching and Learning in Psychology, 1, 229-234.

Allen, I.E., \& Seaman, A. (2010). Learning on demand: Online education in the United States, 2009. Needham, MA: The Sloan Consortium.

Babbie, E.R., Wagner, W.E. \& Zaino, J. (2018). Adventures in social research: Data analysis using IBM® SPSS® statistics $\left(10^{\text {th }}\right.$ ed. $)$. Los Angeles, CA: Sage.

Bransford, J., Derry, S., Berliner, D., \& Hammerness, K. (2005). Theories of learning and their roles in teaching. In L. Darling-Hammond and J. Bransford (Eds.). Preparing teachers for a changing world: What teachers should learn and be able to do (pp. (40-87). San Francisco: Jossey-Bass

Butler, M., Pyzdrowski, L., Goodykoontz, A., \& Walker, V. (2008). The effects of feedback on online quizzes. International Journal for Technology in Mathematics Education,15(4), 131-136.

Chew, P.K.H., \& Dillon, D.B. (2012). Statistics anxiety fluctuates over a semester and decreases with experience. In Proceedings of 24th Annual Convention. From The Association for Psychological Science 24th Annual Convention, May 24-27 2012, Chicago, Illinois, USA. Unpublished manuscript.

Connors, F.A., S.M. Mccown \& B. Roskos-Ewoldsen. (1998). Unique challenges in teaching undergraduate statistics. Teaching of Psychology, 25(1), 40-42.

Delia Deckard, N.M. (2017). Statistics education for undergraduate sociology majors: Survey findings across institutions. Numeracy, 10(2), article 8.

Dykeman, B.F. (2011). Statistics anxiety: Antecedents and instructional interventions. Education, 132(2), 441446.

Everson, M.G., \& Garfield, J. (2008). An innovative approach to teaching online statistics courses. Technology Innovations in Statistics Education, 2(1), article 3.

Ferrandino, Joseph A. 2016. "Student Achievement in Undergraduate Statistics: The Potential Value of Allowing Failure." Journal of the Scholarship of Teaching and Learning 16(6):1-18.

Finney, S.J., \& Schraw, G. (2003). Self-efficacy beliefs in college statistics courses. Contemporary Educational Psychology, 28(1), 161-168.

Forte, J.A. (1995). Teaching statistics without sadistics. Journal of Social Work Education, 31(2), 204-218.

Frankfort-Nachmias, C.,\& Leon-Guerrero, A. (2018). Social statistics for a diverse society. ( $8^{\text {th }}$ ed.).Thousand Oaks, CA: Sage Publications.

Franklin, C., \& Garfield, J. (2006). The GAISE project: Developing statistics education guidelines for pre K-12 and college courses. In G. Burrill (Ed.), Thinking and reasoning with data and chance: 2006 NCTM yearbook (p. 435-475.) Reston, VA: National Council of Teachers of Mathematics.

Kapur, M. (2015). Learning from productive failure. Learning: Research and Practice, 1(1), 58-65.

Kinghorn, J.R. (2014). The new digital divide: Peer collaboration as a bridge. Association for University Regional Campuses of Ohio, 20, 117-132.

Lo, C. (2010). Using SoTL approach in designing and teaching a graduate seminar course. International Journal for the Scholarship of Teaching and Learning, 4(1),1-7.

Macheski, G.E., Buhrmann, J., Lowney, K., \& Bush, M. E.L. (2008). Overcoming student disengagement and anxiety in theory, methods, and statistics courses by building a community of Leaders. Teaching Sociology, 36(1), 42-48.

Miser, W.F. (2005). Educational research-to IRB, or not to IRB? Students as research subjects. Family Medicine, 37(3), 168-173.

Onwuegbuzie, A.J., \& Seaman, M. (1995). The effect of time constraints and statistics anxiety on test performance in a statistics course. Journal of Experimental Education, 63(2), 115-124.

Onwuegbuzie, A.J. (1997). Writing a research proposal: The role of library anxiety, statistics anxiety, and compositional anxiety. Library and Information Science Research, 19(1), 5-33.

Onwuegbuzie, A.J. (2004). Academic procrastination and statistics anxiety. Assessment and Evaluation in Higher Education, 29(1), 3-19. 
Onwuegbuzie, A.J., DaRos, D., and Ryan, J. (1997). The components of statistics anxiety: A phenomenological study. Focus on Learning Problems in Mathematics, 19(4), 11-35.

Pan, W., \& Tang, M. (2004). Examining the effectiveness of innovative instructional methods on reducing statistics anxiety for graduate students in the social sciences. Journal of Instructional Psychology,31(2), 149-159.

Pan, W., \& Tang, M. (2005). Students' perceptions of factors of statistics anxiety and instructional strategies. Journal of Instructional Psychology, 32, 205-214.

Schacht, S.P., \& Stewart, B.J. (1990). What's funny about statistics? A technique for reducing student anxiety. Teaching Sociology, 18(1), 52-56.

Stone, M.T., \& Perumean-Chaney, S. (2011). The benefits of online teaching for traditional classroom pedagogy: A case study for improving face-to-face instruction. Journal of Online Learning and Teaching, 7(3), 393400.

Texas Woman's University. (2018). Undergraduate catalog: Bachelor of Science in sociology. Retrieved from http://catalog.twu.edu/undergraduate/arts-sciences/sociology-social-work/sociology-bs/

University of Nebraska-Lincoln. (2017). Evaluating learning and assessing teaching: Assessing your teaching. Office of Graduate Studies, Teaching at UNL. Retrieved from https://www.unl.edu/gtahandbook/assessing-your-teaching

Waples, J.A. (2016). Teacher-ready research review: Building emotional rapport with students in statistics courses. Scholarship of Teaching and Learning in Psychology, 2(4), 285-293.

Zimmerman, W.A., and Johnson, G. (2017). Exploring factors related to completion of an online undergraduatelevel introductory statistics course. Online Learning, 21(3), 191-205. 